\title{
Developing Genetic Variability of Quinoa (Chenopodium quinoa Willd.) with Gamma Radiation for Use in Breeding Programs
}

\author{
Luz Rayda Gomez-Pando, Ana Eguiluz-de la Barra
}

Cereal and Native Grain Research Program, National Agricultural University La Molina, Lima, Peru.

Email: luzgomez@lamolina.edu.pe

Received November 22 ${ }^{\text {nd }}, 2012$; revised December $23^{\text {rd }}, 2012$; accepted December $31^{\text {st }}, 2012$

\begin{abstract}
Quinoa (Chenopodium quinoa Willd.) is a staple food produced mainly by small-scale subsistence farmers in Peru's highland. Dry seeds (cv. Pasankalla) were irradiated with doses of $150 \mathrm{~Gy}, 250 \mathrm{~Gy}$ and $350 \mathrm{~Gy}$. In the $\mathrm{M}_{1}$ generation, the germination process was delayed with increasing radiation dose; seedling height, root length and leaf development were most reduced at $250 \mathrm{~Gy}$ and at $350 \mathrm{~Gy}$, no plants survived. In $\mathrm{M}_{2}$, the maximum spectrum of chlorophyll mutations corresponded to $150 \mathrm{~Gy}$ and the maximum frequency to $250 \mathrm{~Gy}$. The chlorine mutation was predominant, followed by xantha. Changes were registered for branch number, pedicel length, plant height, life-cycle duration, stem and foliage colour, and leaf morphology at the two doses, with improvements in plant type. More than one mutation per plant was found, especially at $250 \mathrm{~Gy}$. In $\mathrm{M}_{3}$, the same spectrum of mutations was observed, along with a valuable change in grain colour.
\end{abstract}

Keywords: Chenopodiun quinoa; Gamma Rays; Mutant

\section{Introduction}

Quinoa (Chenopodium quinoa Willd.) is native crop of the Andes. Quinoa is cultivated in Peru by small farmers in plots below of 1 ha [1]. Its tolerance to drought, frost and saline soils makes it important in highland farming systems [2,3]. This annual crop belongs to the Chenopodiaceae (goosefoot) family. Quinoa has an exceptionally nutritious balance of protein, fat, oil and starch. Grains average $16 \%$ protein, higher than common cereals. Moreover, the protein is of unusually high quality, and is close to the FAO standard for human nutrition. Quinoa protein is high in the essential amino acids lysine, methionine and cystine, making it complementary to both other grains (deficient in lysine) and legumes (deficient in methionine and cystine) [4-6].

Quinoa is planted mostly in Puno to altitudes of over $3800 \mathrm{~m}$. Due to the stressful climatic conditions and the technology in use there, productivity is low; for many years it ranged from 900 to $1100 \mathrm{~kg} / \mathrm{ha}$ [1]. There are many ways to improve crop performance: one of them is genetic improvement via mutation induction. According to the IAEA database, there are more than 2500 mutant varieties of more than 170 different species [7]. There are many reports of improved morphological and physiological characteristics in cereals, grain legumes, oil seeds, fiber crops, vegetables and ornamentals following mutation induction, with gamma rays being the preferred agent, and plant type and yield are the traits most commonly reported [8-10]. Although the quality of many crops has been improved thru mutation induction [11], to the best of our knowledge, this technique has not been applied in quinoa to improve its agricultural performance in the marginal conditions of the Peruvian highlands but it was applied in barley and Amaranthus [12].

The Cereal and Native Grain Research Program at the National Agricultural University La Molina (Peru) is making efforts to improve the early cultivar PasankallaINIA, which has a growing period of 140 days; the plant can measure up to $120 \mathrm{~cm}$ in height; its panicle is light purple, and it has a glomerular inflorescence of intermediate density. Seeds have a reddish-brown pericarp and the episperm (seed coat) is lead-colored.

\section{Materials and Methods}

\subsection{Plant Material}

Two hundred grams of dry quinoa seeds with $12 \%$ of moisture of cv. Pasankalla were irradiated with gamma rays at the Peruvian Institute of Nuclear Energy (IPEN), at doses of 150, 250 and $350 \mathrm{~Gy}$. Non-irradiated seeds were used as controls in each evaluation. Seeds have to 
be delivered for irradiation to a nuclear centre. Such centres have been established in most countries or at IAEA Headquarters in Vienna.

\subsection{Percent of Germination in $M_{1}$ Generation}

To establish percent of germination, 100 seeds per Petri dish (Ø: $10 \mathrm{~cm}$, height: $2 \mathrm{~cm}$ ) were placed on filter paper and covered with tissue paper. Each treatment included four Petri dishes (replicates) (for a total of 400 seeds per treatment). Distilled water $(5 \mathrm{ml})$ was added at the beginning of the experiment. Every dish was then irrigated daily with $1 \mathrm{ml}$ water to maintain moisture. The experiment was conducted under a photosynthetic photon flux density of $458 \mu \mathrm{mol} / \mathrm{m}^{2} \mathrm{~s}(12 \mathrm{~h} /$ day $)$ at $20^{\circ} \mathrm{C}$. The germination percentage was recorded on days $3,5,7,9,11$ and 15 .

\subsection{Physiological Damage in $M_{1}$ Generation}

To determine the physiological damage or somatic effects caused by the irradiation, seedling height and root length were measured in 1-month-old plants using the "sandwich blotter" technique [17]. Thirty seeds from each treatment were used in this experiment in four replicates (for a total 120 seeds per treatment). The level of somatic effects after mutagenic treatment can be evaluated on the basis of various parameters, including delay in seed germination; level of disturbances in the cell cycle; reduced seedling emergence; reduced seedling and plant growth; appearance of chlorophyll defects; and reduced fertility and plant survival. The term "reduced" indicates change in expression of a particular character in relation to the control, usually the parent cultivar or the breeding line whose seeds were treated with a mutagen [14]. The rest of the seeds from each treatment were sown in beds under field conditions following the protocol described for quinoa crop in Peru [15]. The formation of cotyledonal and true leaves and percent of survival were evaluated. Individual heads or inflorescences of the $\mathrm{M}_{1}$ generation were harvested. Data were analyzed using a completely randomized design.

\subsection{Evaluation of $\mathbf{M}_{2}$ Generation}

The $\mathrm{M}_{2}$ population was cultivated in the field, one inflorescence per row. The following traits were evaluated: chlorophyll mutations, life-cycle duration, plant height, and morphological characteristics. Putative mutants were identified and harvested separately as individual plants. This generation was cultivated following the protocol described for different crops under isolated field conditions [14].

\subsection{Evaluation of $\mathrm{M}_{3}$ Generation}

The selected putative $\mathrm{M}_{2}$ mutants were cultivated as row/ plant (in the field, one plant per row) for progeny determination and homozygosity testing. This generation was cultivated following the protocol described for different crops under field conditions planted in a row or rows depending on the amount of seed [14].

\subsection{General Experimental Scheme}

Figure 1 shows the experimental scheme followed in this research.

\subsection{Data Analysis}

The Statistical Package for Social Sciences (Version 17.0 for Windows, SPSS Inc.) was used to perform ANOVA and Tukey tests $(\mathrm{p} \leq 0.05)$.

\section{Results and Discussion}

\subsection{Analysis of $M_{1}$ Generation}

Germination of the control, non-irradiated seeds was normal, reaching $100 \%$ at 7 days. In contrast, the germination process was slow in the irradiated seeds, becoming slower as the dose increased (Table 1). At 15 days, germination of all treated seeds had reached $99 \%$. The effect of the radiation was evident only during the germination process.

Radiosensitivity was also evaluated by looking for physiological damage in the developing seedlings. Statistical differences were found by One-Way ANOVA and Tukey tests in root length and seedling height among the controls and all evaluated treatments (150, 250 and 350 Gy) (Table 1).

Under field conditions, using a scale that reflects the phenological stages of quinoa development during vegetative growth [16], differences were observed among the treated plants and controls (Table 1). The control plants

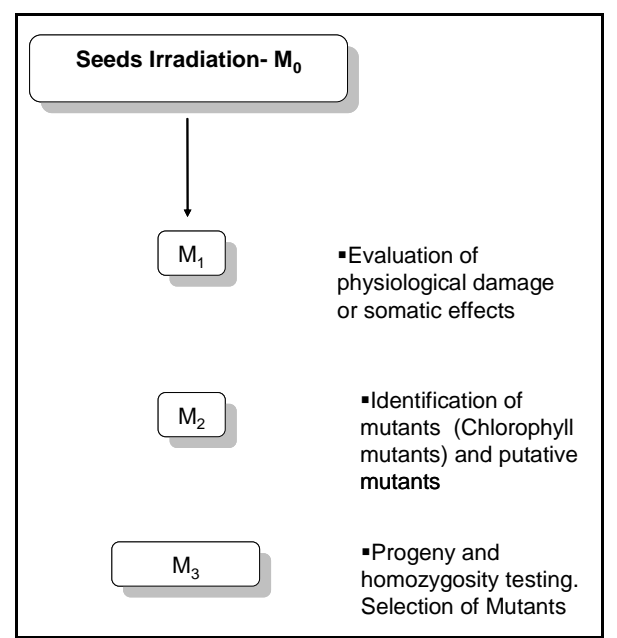

Figure 1. Experimental scheme followed in this research. 
Table 1. Germination and early growth of quinoa (Chenopodium quinoa Willd.) cv. Pasankalla following gamma-irradiation treatment.

\begin{tabular}{|c|c|c|c|c|c|}
\hline \multicolumn{2}{|c|}{ Gamma ray dose (Gy) } & 0 & 150 & 250 & 350 \\
\hline \multirow{6}{*}{ Germination $(\%)^{1}$} & 3 days & $53 \mathrm{a}$ & $30 \mathrm{~b}$ & $25 \mathrm{c}$ & $20 \mathrm{~d}$ \\
\hline & 5 days & $78 \mathrm{a}$ & $55 \mathrm{~b}$ & $49 \mathrm{c}$ & $41 \mathrm{~d}$ \\
\hline & 7 days & $100 \mathrm{a}$ & $71 \mathrm{~b}$ & $63 \mathrm{c}$ & $52 \mathrm{~d}$ \\
\hline & 9 days & $100 \mathrm{a}$ & $84 \mathrm{~b}$ & $77 \mathrm{c}$ & $68 \mathrm{~d}$ \\
\hline & 11 days & $100 \mathrm{a}$ & $99 \mathrm{a}$ & $84 \mathrm{~b}$ & $79 \mathrm{c}$ \\
\hline & 15 days & $100 \mathrm{a}$ & 99 a & 99 a & $99 \mathrm{a}$ \\
\hline \multicolumn{2}{|c|}{ Root length at 30 days of germination $(\mathrm{cm})$} & $7.23 \mathrm{a}$ & $4.58 \mathrm{~b}$ & $4.07 \mathrm{~b}$ & $2.80 \mathrm{c}$ \\
\hline \multicolumn{2}{|c|}{ Seedling height at 30 days of germination $(\mathrm{cm})$} & $3.81 \mathrm{a}$ & $3.05 \mathrm{~b}$ & $2.73 \mathrm{bc}$ & $2.55 \mathrm{c}$ \\
\hline \multirow{5}{*}{$\begin{array}{l}\text { Days required for leaf } \\
\text { formation }^{2}\end{array}$} & Cotyledonal leaves & $10 \mathrm{~b}$ & $12 \mathrm{~b}$ & $15 \mathrm{a}$ & $15 \mathrm{a}$ \\
\hline & $1^{\text {st }}$ pair of true leaves & $8 \mathrm{c}$ & $14 \mathrm{~b}$ & $18 \mathrm{a}$ & \multirow{4}{*}{$\begin{array}{l}\text { True leaves were not } \\
\text { formed in this treatment. }\end{array}$} \\
\hline & $2^{\text {nd }}$ pair of true leaves & $14 \mathrm{c}$ & $19 \mathrm{~b}$ & $25 \mathrm{a}$ & \\
\hline & $3^{\text {rd }}$ pair of true leaves & $18 \mathrm{c}$ & $27 \mathrm{~b}$ & $30 \mathrm{a}$ & \\
\hline & $4^{\text {th }}$ pair of true leaves & $22 \mathrm{c}$ & $30 \mathrm{~b}$ & $34 \mathrm{a}$ & \\
\hline \multicolumn{2}{|c|}{ Plant survival at 30 days of field growth (\%) ${ }^{1}$} & $80 \mathrm{a}$ & $53 \mathrm{~b}$ & $28 \mathrm{c}$ & $0 \mathrm{~d}$ \\
\hline
\end{tabular}

In each row, results with the same letter are not statistically different (One-Way ANOVA, Tukey, $\mathrm{p}>0.05$ ). ${ }^{1}$ For statistical analyses only, percentages were transformed according to $\mathrm{y}^{\prime}=2$ arcsine $\left((\mathrm{y} / 100)^{0.5}\right) .{ }^{2}$ For statistical analyses only, the numbers of days required for leaf formation were transformed according to $\mathrm{y}^{\prime}=\mathrm{y}^{0.5}$.

and the plants from the 150 and $250 \mathrm{~Gy}$ treatments advanced from germination to vegetative growth, but the 350 Gy-treated plants did not. In this latter treatment, the plants did not form leaves and none of them survived. Number of days to leaf development increased with increasing dosage of gamma rays. We observed $80 \%$ survival in the control, 53\% survival in the 150 Gy treatment and $28 \%$ survival in the 250 Gy treatment.

\subsection{Analysis of $\mathbf{M}_{2}$ Generation}

Table 2 presents the frequency and spectrum of chlorophyll mutations: the maximum spectrum corresponded to $150 \mathrm{~Gy}$ and the maximum frequency to $250 \mathrm{~Gy}$. The chlorina mutation was predominant, followed by the xantha mutation. The frequency of chlorophyll mutations increased with increasing dosage. Leaf pigment mutations were observed at $150 \mathrm{~Gy}$, as a change in cotyledon leaf color from green to pink, at a frequency of $0.086 \%$ (Table 2).

Table 2 also presents the entire spectrum of morphological and physiological mutations observed among the irradiated plants. Changes were registered for branch number and pedicel length, stem and foliage color, plant height and life cycle (both reduced), leaf morphology (spoon type) and plant type (improved).

In the 150 Gy treatment, the highest frequencies corresponded to vigorous plant (growth) and branching (Table 2). In the 250 Gy treatment, higher frequencies were found for plants with cream-colored grains and light green foliage. A similar frequency spectrum was found at each dose, but there were more mutations per plant at the higher doses. Some of the possible mutant plants did not give seeds.

\subsection{Analysis of $\mathbf{M}_{3}$ Generation}

The changes in morphological and physiological characteristics identified in the $\mathrm{M}_{2}$ generation, in general, were observed in the $\mathrm{M}_{3}$ generation, confirming the mutations (Table 3). The light green foliage observed in $\mathrm{M}_{2}$; almost phosphorescent, was not observed at $\mathrm{M}_{3}$ generation. The most valuable changes were those of grain color on the pericarp from reddish-brown to cream and on the episperm (seed coat) from lead to cream and plant height reduction.

The response observed in quinoa to gamma ray irradiation treatments showed similar somatic effects to that reported to other crops at $\mathrm{M}_{1}$ generation. The root length and seedling height of generation $\mathrm{M}_{1}$ decreased proportionally to dosage amount (Table 1), as reported for other crops [14,17] and the identification of irradiation dosage limit of 350 Gy for cv. Pasankalla [18]. One peculiar response of quinoa to the damage of irradiation is the longer time for true leaf formation and the absence of them at high dose finishing with the death of the seedlings.

In similar way, radiation genetic effects were observed in generation $\mathrm{M}_{2}$ and $\mathrm{M}_{3}$. Mutation of different characters were founded (Tables 2 and $\mathbf{3}$ ) as reported in other crops $[9,19,20]$. In quinoa at seedling stages chlorophyll and anthocyanin mutations were observed as early indicator 
Table 2. Spectrum and frequency of mutations in $\mathrm{M}_{2}$ generation of quinoa (Chenopodium quinoa Willd.) cv. Pasankalla following gamma-irradiation treatment at doses of 150 and $250 \mathrm{~Gy}$.

\begin{tabular}{|c|c|c|c|c|c|}
\hline \multicolumn{3}{|c|}{$150 \mathrm{~Gy}$ (total number of plants studied $=55,758$ ) } & \multicolumn{3}{|c|}{$250 \mathrm{~Gy}$ (total number of plants studied $=10,372$ ) } \\
\hline & $\begin{array}{l}\text { No. of } \\
\text { mutants }\end{array}$ & $\begin{array}{c}\text { Mutation } \\
\text { frequency }(\%)\end{array}$ & & No. of mutants & Mutation frequency $(\%)$ \\
\hline \multicolumn{6}{|c|}{ Chlorophyll and leaf pigment mutations } \\
\hline Xantha & 20 & 0.036 & Chlorina & 10 & 0.096 \\
\hline Leaf color: anthocyanin (pink) & 48 & 0.086 & & & \\
\hline \multicolumn{6}{|c|}{ One characteristic modified by gamma-irradiation } \\
\hline Improved plant type & 48 & 0.086 & Improved plant type & 6 & 0.058 \\
\hline Reduced plant height & 1 & 0.002 & Earliness & 1 & 0.010 \\
\hline Branching habit & 47 & 0.085 & Grain colour & 50 & 0.480 \\
\hline Light-green foliage & 25 & 0.045 & & & \\
\hline Lateness & 2 & 0.004 & & & \\
\hline Increased flower pedicel & 1 & 0.002 & & & \\
\hline Purple stem & 1 & 0.002 & & & \\
\hline \multicolumn{6}{|c|}{ Two characteristics modified by gamma-irradiation } \\
\hline Improved plant type and earliness & 11 & 0.020 & $\begin{array}{l}\text { Improved plant type } \\
\text { and reduced plant height }\end{array}$ & 2 & 0.019 \\
\hline $\begin{array}{l}\text { Improved plant type and stem with purple } \\
\text { streaks }\end{array}$ & 3 & 0.005 & $\begin{array}{l}\text { Improved plant type } \\
\text { and branching habit }\end{array}$ & 6 & 0.058 \\
\hline $\begin{array}{l}\text { Improved plant type and increased plant } \\
\text { height }\end{array}$ & 1 & 0.002 & $\begin{array}{l}\text { Improved plant type } \\
\text { and earliness }\end{array}$ & 9 & 0.086 \\
\hline $\begin{array}{l}\text { Improved plant type and increased flower } \\
\text { pedicel }\end{array}$ & 1 & 0.002 & $\begin{array}{l}\text { Reduced plant height } \\
\text { and earliness }\end{array}$ & 2 & 0.019 \\
\hline Improved plant type and branching habit & 6 & 0.011 & $\begin{array}{l}\text { Reduced plant height } \\
\text { and light-green foliage }\end{array}$ & 4 & 0.038 \\
\hline Improved plant type and light-green foliage & 10 & 0.018 & $\begin{array}{l}\text { Branching habit and } \\
\text { light-green foliage }\end{array}$ & 58 & 0.557 \\
\hline Reduced plant height and earliness & 2 & 0.004 & $\begin{array}{l}\text { Improved plant type and } \\
\text { compact inflorescence }\end{array}$ & 1 & 0.010 \\
\hline Reduced plant height and light-green foliage & 8 & 0.001 & Branching habit and earliness & 1 & 0.010 \\
\hline Branching habit and purple stem & 1 & 0.002 & Branching habit and lateness & 1 & 0.010 \\
\hline Branching habit and increased plant height & 4 & 0.007 & & & \\
\hline Branching habit and reduced plant height & 9 & 0.016 & & & \\
\hline Branching habit and light-green foliage & 10 & 0.018 & & & \\
\hline Earliness and light-green foliage & 2 & 0.004 & & & \\
\hline
\end{tabular}

Three characteristics modified by gamma-irradiation 


\section{Continued}

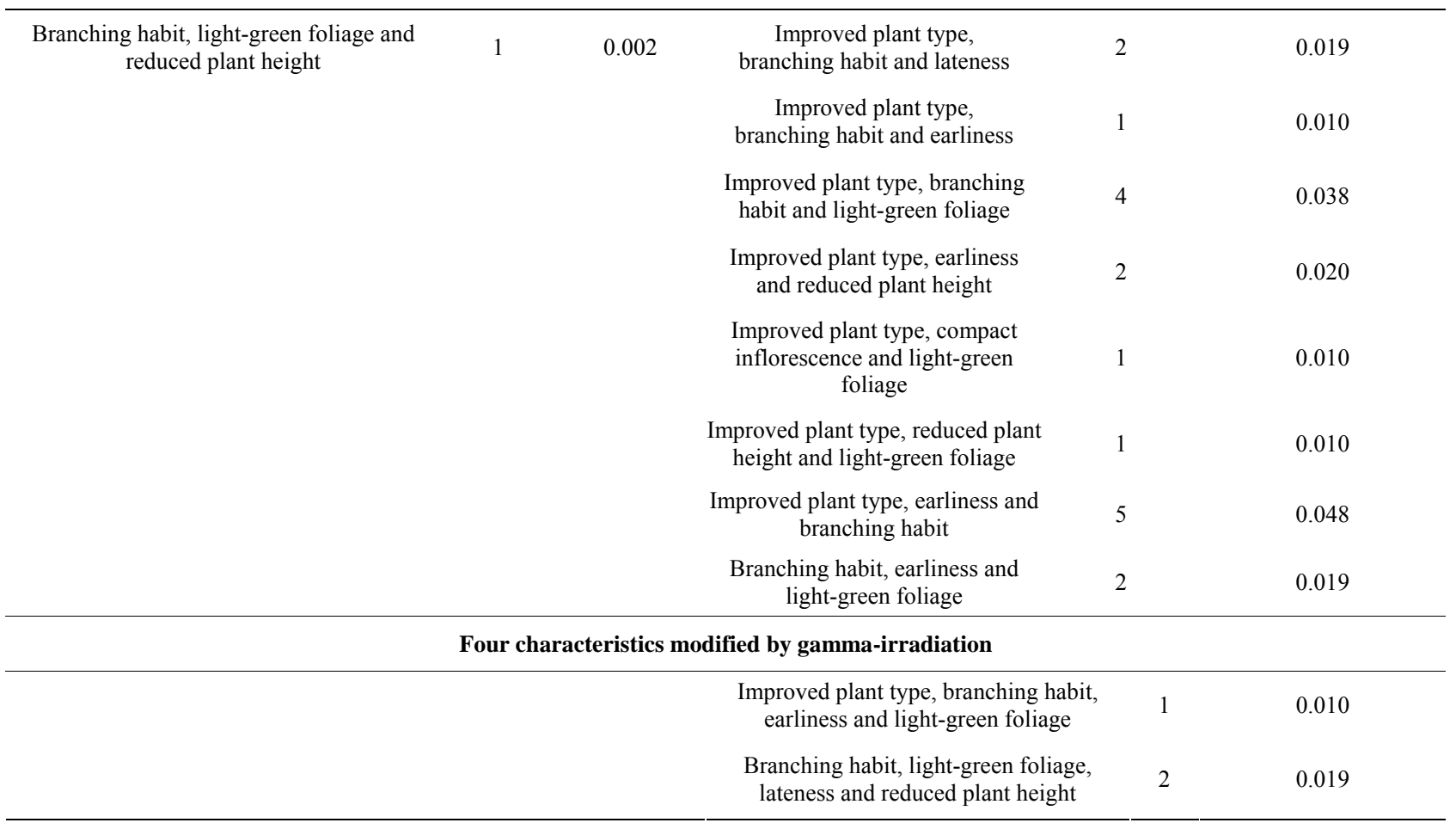

Table 3. Spectrum and percentage of plants showing mutation in $\mathbf{M}_{3}$ generation of quinoa (Chenopodium quinoa Willd.) cv. Pasankalla following gamma-irradiation treatment at doses of 150 and $250 \mathrm{~Gy}$.

\begin{tabular}{|c|c|c|}
\hline $\mathbf{M}_{2}$-Mutation type & $\mathbf{M}_{3}$-Mutation type & $\%$ of mutation type in $\mathrm{M}_{3}$ \\
\hline \multicolumn{3}{|c|}{ One characteristic } \\
\hline Improved plant type & Improved plant type & 57 \\
\hline Earliness & Earliness & 100 \\
\hline Grain color & Grain color & 100 \\
\hline \multicolumn{3}{|c|}{ Two characteristics } \\
\hline Improved plant type and reduced plant height & Improved plant type and reduced plant height & 25 \\
\hline Improved plant type and branching habit & Improved plant type and branching habit & 100 \\
\hline Improved plant type and earliness & Improved plant type and earliness & 100 \\
\hline Reduced plant height and earliness & Reduced plant height and earliness & 37.5 \\
\hline Improved plant type and compact inflorescence & Improved plant type and compact inflorescence & 100 \\
\hline Branching habit and earliness & Branching habit and earliness & 100 \\
\hline Branching habit and lateness & Branching habit and lateness & 100 \\
\hline \multicolumn{3}{|c|}{ Three characteristics } \\
\hline Improved plant type, branching habit and lateness & Improved plant type, branching habit and lateness & 100 \\
\hline Improved plant type, branching habit and earliness & Improved plant type, branching habit and earliness & 100 \\
\hline Improved plant type, earliness and reduced plant height & Improved plant type, earliness and reduced plant height & 35.5 \\
\hline Improved plant type, earliness and branching habit & Improved plant type, earliness and branching habit & 100 \\
\hline
\end{tabular}


of mutation occurrence, similar to sesame, where four types of chlorophyll mutations have been reported: xantha, chlorina, striate and xantha viridis [21].

\section{Conclusions}

It is important to highlight valuable agronomic changes observed in this population thru mutation, considering that this crop was neglected by many decades and a minimum genetic improvement work was made until now. The farmers are still using land races with very long cycle and very high height plants [22], being these characters negative limiting factors for the introduction of quinoa to modern agricultural systems. Identified mutants with reduced life cycle, could be beneficial considering that some of the actual cultivars growing have long-cycle reaching over 7 months in the field with the flowering and grain maturity time under adverse weather conditions (drought and frost) that significantly reduce the performance. In similar way the identified mutants with reduction in plant height will be very useful considering that will reduce the high tendency to lodging and could improve the yield in similar way to that achieved in wheat [23-25].

The mutation in grain color of quinoa will be very important for some industrial use. This change also was reported in wheat, where light-colored grain mutants have been obtained from Pusa Lerma [26], Tonari 71 [27] and Sonora 64 [9] and were very appreciated by the end users.

Other important aspect observed in this study was that cv. Pasankalla explodes when roasted, similar to popcorn. This feature is retained in the mutants, with the added value of a final product that has a more appealing commercial appearance. The selected mutants will be evaluated for their agronomic performance in the next generations.

\section{Acknowledgements}

This research was supported by: IAEA-PROJECT PER/ 5/30 "Genetic Improvement of Quinoa (Chenopodium quinoa) and Kiwicha (Amaranthus caudatus) using $\mathrm{Mu}-$ tation Induction and Biotechnology", INCA-GRO-PERU: Sub-Proyecto "Mejoramiento Genético de la Quinua para el desarrollo sostenible del cultivo en la sierra central" and Program IUC/VLIR-UNALM: Development of value chains for biodiversity conservation and improvement of rural livelihoods. Thanks to Mrs. Camille Vainstein for professional language editing of the manuscript.

\section{REFERENCES}

[1] Peruvian Ministry of Agriculture, 2012.

http://www.minag.gob.pe/estadistica-agraria-mensual/htm
[2] C. J. Risi and N. W. Galwey, "The Chenopodium Grains of the Andes: Inca Crops for Modern Agriculture," Advanced and Applied Biology, Vol. 10, 1984, pp. 145-216.

[3] S. E. Jacobsen, A. Mujica and C. R. Jensen, "The Resistance of Quinoa (Chenopodium quinoa Willd.) to Adverse Abiotic Factors," Food Reviews International, Vol. 19, No. 1-2, 2003, pp. 99-109. doi:10.1081/FRI-120018872

[4] R. E. Aluko and E. Monu, "Functional and Bioactive Properties of Quinoa Seed Protein Hydrolysates," Journal of Food Science, Vol. 68, No. 4, 2003, pp. 1254-1258. doi:10.1111/j.1365-2621.2003.tb09635.x

[5] R. Repo-Carrasco, C. Espinoza and S. E. Jacobsen, "Nutritional Value and Use of the Andean Crops Quinoa (Chenopodium quinoa) and Kañiwa (Chenopodium pallidicaule)," Food Reviews International, Vol. 19, No. 1-2, 2003, pp. 179-189. doi:10.1081/FRI-120018884

[6] L. Abugoch, E. Castro, C. Tapia, M. C. Añón, P. Gajardo, and A. Villarroel, "Stability of Quinoa Flour Proteins (Chenopodium quinoa Willd.) during Storage," International Journal of Food Science \& Technology, Vol. 44, No. 10, 2009, pp. 2013-2020.

doi:10.1111/j.1365-2621.2009.02023.x

[7] IAEA, 2012. http://www-mvd.iaea.org/MVD/default.htm

[8] B. S. Ahloowalia, M. Maluszynski and K. Nichterlein, "Global Impact of Mutation-Derived Varieties," Euphytica, Vol. 135, No. 2, 2004, pp. 187-204. doi:10.1023/B:EUPH.0000014914.85465.4f

[9] V. L. Chopra, "Mutagenesis: Investigating the Process and Processing the Outcome for Crops Improvement," Current Science, Vol. 89, No. 2, 2005, pp. 353 -359.

[10] H. W. Fu, Y. F. Li and Q. Y. Shu, "A Revisit of Mutation Induction by Gamma Rays in Rice: Implications of Microsatellite Markers for Quality Control," Molecular Breeding, Vol. 22, No. 2, 2008, pp. 281-288. doi:10.1007/s11032-008-9173-7

[11] O. F. Adekola and F. Oluleye, "Influence of Mutation Induction on the Chemical Composition of Cowpea Vigna unguiculata (L.) Walp," African Journal of Biotechnology, Vol. 6, 2007, pp. 2143-2146.

[12] L. Gómez-Pando, A. Eguiluz, J. Jimenez, J. Falconí and E. Heros, "Barley (Hordeun vulgare) and Kiwicha (Amaranthus caudatus) Improvement by Mutation Induction in Peru," In: Q. Y. Shu, Ed., Induced Plant Mutations in the Genomics Era, Food and Agriculture Organization of the United Nations, Rome, 2009, pp. 371-374.

[13] R. R. Myhill and C. F. Konzak, "A New Technique for Culturing and Measuring Barley Seedlings," Crop Science, Vol. 7, No. 3, 1967, pp. 275-277. doi:10.2135/cropsci1967.0011183X000700030038x

[14] M. Maluszynsski, I. Szarejko, Ch. Bathia, K. Nichterlein, and P. Lagoda, "Methodologies for Generating Variability. Part 4: Mutation Techniques," In: Plant Breeding and Farmer Participation, Food and Agriculture Organization of the United Nations, Rome, 2009. 159 -194

[15] A. Mujica, "Cultivo de Quinua," INIA, Serie Manual RI, No. 1-97, Instituto Nacional de Investigación Agraria, 
Dirección General de Investigación Agraria, Lima, 1997, p. 130.

[16] H. Limburg and H. D. Mastebroek, "Breeding High Yielding Lines of Chenopodium quinoa Willd. with Saponin Free Seed," Small Grain Cereals and Pseudo Cereals Workshop: Crop Development for the Cool and Wet Regions of Europe, The Royal Veterinary and Agricultural University, Copenhagen, 1996, pp. 103-114.

[17] A. A. Cheema and B. M. Atta, "Radiosensitivity Studies in Basmati Rice," Pakistan Journal of Botany, Vol. 35, No. 2, 2003, pp. 197-207.

[18] J. N. Tabosa, W. Colaco, O. V. Reis, J. B. Simplicío and F. M. Dias, "Sorghum Genotypes Tolerant to Soil Salinity-Progenies Developed under Gamma Ray Doses," E Journal.icrisat.org, Vol. 5, No. 1, 2007, pp. 1-5.

[19] J. Encheva, M. Christov, N. Nenov, F. Tsvetkova, P. Ivanov, P. Shindrova and V. Encheva, "Developing Genetic Variability in Sunflower (Helianthus annuus L.) by Combined Use of Hybridization with Gamma Radiation or Ultrasound," Helia, Vol. 26, No. 38, 2003, pp. 99-108. doi:10.2298/HEL0338099E

[20] Y. Chen, L. S. Lee, H. Hill, R. Henry and C. Banos, "Rough Texture of Mungbean (Vigna radiata L.) First True Leaves Induced by Gamma Irradiation," Plant Mut Rep, Vol. 2, No. 1, 2008, pp. 39-43.

[21] A. Sheeba, S. M. Ibrahim, S. Yogameenakshi and S. Babu, "Mutagen Induced Polygenic Variability in Sesame
(Sesamum indicum L.)," Madras Agricultural Journal, Vol. 91, No. 1-3, 2004, pp. 75-78.

[22] M. E. Tapia, "Cultivos Andinos Subexplotados y $\mathrm{Su}$ Aporte a la Alimentación," 2nd Edition, Oficina Regional de la FAO para America Latina y el Caribe, Santiago, 2000.

[23] Y. Zhou, Z. H. He, X. X. Sui, X. C. Xia, X. K. Zhang, and G. S. Zhang, "Genetic Improvement of Grain Yield and Associated Traits in the Northern China Winter Wheat Region from 1960 to 2000," Crop Science, Vol. 47, No. 1, 2007, pp. 245-253. doi:10.2135/cropsci2006.03.0175

[24] J. Rutger, "Induced Semidwarf Mutants," Rice Genetics Newsletter, Vol. 1, 1984, pp. 92-93.

[25] A. Sasaki, M. Ashikari, M. Ueguchi-Tanaka, H. Itoh, A. Nishimura, D. Swapan, K. Ishiyama, T. Saito, M. Kobayashi, G. S. Khush, H. Kitano and M. Matsuoka, "Green Revolution: A Mutant Gibberellin-Synthesis Gene in Rice," Nature, Vol. 416, No. 6882, 2002, pp. 701-702. doi:10.1038/416701a

[26] M. S. Swaminathan, "Biological Effects of Neutron Irradiations," Current Science, Vol. 33, 1964, pp. 299-300.

[27] R. N. Sawhney, V. L. Chopra, K. Rajinder and H. R. Mohindroo, "Radiation Induced Amber-Grained Mutants in Variety Tonari 71 of Wheat," Current Science, Vol. 46, 1977, pp. $317-318$. 